\title{
ZDRAVSTVENO EKOLOŠKI ASPEKTI RAZVOJA GOLF TURIZMA U HRVATSKOJ I BOSNI I HERCEGOVINI
}

\author{
Aleksandar Racz \\ Zdravstveno veleučilište, 10000 Zagreb \\ Rad je primljen 5.4.2017. Rad je recenziran 10.4.2017. Rad je prihvaćen 25.4.2017.
}

\section{SAŽETAK}

UVOD: Strategija razvoja turizma Republike Hrvatske do 2020. godine predstavlja cjelovit konceptualni okvir koji omogućava koordinirano djelovanje nositelja i sustavno usuglašavanje mjera turističke politike, cjelovito razumijevanje ključnih pravaca razvoja hrvatskog turizma kao preduvjeta privlačenja interesa potencijalnih domaćih i stranih ulagača, te ciljano usmjeravanje razvojno-investicijskog procesa i efikasno povlačenje sredstava Europskih fondova. U podsegmentima turističke ponude koji se u Strategiji razvoja turizma RH do 2020. označavaju kao „podsegmenti s izraženom perspektivnom razvoja“, pored zdravstvenog turizma, cikloturizma, gastronomije i enologije, planinskog i ruralnog turizma i ekoturizma ističe i golf turizam. Ekspanzija razvoja golf turizma u regiji vidljiva je i kroz činjenicu da se na listi kapitalnih investicijskih projekata za Federaciji Bosne i Hercegovine uz sektore poljoprivrede, energetike, industrije, prometa, turizma i zaštite životne sredine nalaze se i golf tereni u Mostaru. Budući da se pri odabiru lokacija i tijekom izrade obaveznih Studija utjecaja na okoliš ne provodi povezivanje i procjena negativnih utjecaja zahvata u prostoru na krajobraz, staništa i okoliš promatran kroz floru i faunu sa nedvojbenim i zdravstveno ekološkim posljedicama po lokalno stanovništvo i širu zajednicu, nužan je princip predostrožnosti prema izgradnji golf terena.

CILJ: Cilj rada je, sa zdravstveno ekološkog i bioetičkog aspekta, analizirati negativne posljedice izgradnje golf resorta na okoliš i osvijestiti potencijalne zdravstveno ekološke učinke, te na temelju hrvatskih iskustava ukazati na potrebu izuzetnog opreza prilikom odobrenja izgradnje golf terena u okolici Mostara radi cjelokupne zaštite doline Neretve.

METODE: U radu su korišteni sekundarni izvori informacija koji su podvrgnuti postupcima indukcije i dedukcije, analize i sinteze, te metode komparacije, deskripcije i klasifikacije.

REZULTATI: Rezultati pokazuju da svaka izgradnja golf terena izrazito doprinosi devastaciji krajobraza, a bioraznolikost životinjskih i biljnih vrsta postaje žrtvom profita investitora. S zdravstvenog ekološkog aspekta najvažnija je visoka potrošnja vode za navodnjavanje golf terena i u pratećim objektima, uz negativne posljedice smanjenja rezervi podzemne pitke vode u izvorištu te bioakumulacija umjetnih gnojiva, potom pesticida, insekticida i herbicida sustavno korištenih u okolišu golf resorta. Zbog navedenog prilikom izrade studija utjecaja na okoliš mora se u timove koji izrađuju studije utjecaja na okoliš uključiti i zdravstveno ekološke stručnjake kako bi se izbjegle trajne i nesagledive štete i opterećenje okoliša.

ZAKLJUČAK: Zaključak rada opravdava argumente ekoloških aktivista i filozofska razmatranja bioetičkih skeptika koji smatraju da je cijena koju plaća okoliš i rizik po lokalnu zajednicu prevelik u odnosu na korist dobivenu kroz razvoj golf turizma. Iskustvo Hrvatske mora biti važno i za područje Bosne i Hercegovine, posebno dijelova uz dolinu hercegovačkih rijeka i plodnog tla korištenog u vinogradarstvu, te za uzgoj agruma, voća i povrća, budući da šteta nanesena okolišu i opasnosti po zdravlje lokalnog stanovništva definitivno ne opravdava klijentelizam i pogodovanje financijskom probitku uskog kruga investitora u izgradnju golf terena kao izgovora za apartmanizaciju prostora.

Ključne riječi: Bioraznolikost, pesticidi, voda, održivi razvoj, javno zdravstvo, golf turizam

Osoba za razmjenu informacija:

Doc.dr. Aleksandar Racz

email: aracz@zvu.hr 


\section{UVOD}

Europska unija (EU) prepoznaje Hrvatsku kao turističku destinaciju kojoj je cilj maksimalno iskoristi vlastite potencijale, a u interesu rasta svekolikog hrvatskog blagostanja, koristeći pritom vrijednosni sustav održivog razvoja i konkurentske strategije EU na području turizma. Polazeći od takvih premisa, definirana je Strategija razvoja turizma RH do 2020. (u daljnjem tekstu Strategija), u kojoj se polazi od analize ključnih pokazatelja dostignutog razvoja, sagledavaju razvojna ograničenja i razvojne mogućnosti koje se očitavaju iz relevantnih razvojnih trendova u globalnom okruženju te prepoznaju ključni činitelji uspjeha na koje se hrvatska turistička politika mora usredotočiti u razdoblju do 2020. godine (1). Vlada RH priliku vidi u realizaciji mogućih značajnih prihoda od golf turizma, pretpostavivši da Hrvatska u tom segmentu ima izvanrednu komparativnu prednost kao najbliža topla destinacija u kojoj golferi s velikog tržišta srednje i istočne Europe mogu igrati golf cijelu godinu (2). Polazna premisa je da razvijenije sredine već desetljećima prate razvoj golfa i žive od njega pa se postavlja pitanje uključenja i Hrvatske. Naime, najpopularnija destinacija turista-golfera u Europi je područje Sredozemlja, prvenstveno zbog povoljne klime i atraktivnih igrališta. U tom smislu smatra se da bi razvojem golf turizma Hrvatska dala značajni doprinos rješavanju dijela kroničnog problema sezonalnosti pogotovo $\mathrm{u}$ obalnom području pretpostavivši da bi golf turisti mogu napuniti slabo popunjene postojeće kvalitetne hotelske kapacitete izvan glavne turističke sezone i pridonijeti značajnom rastu vanpansionske potrošnje. Naime, ne samo u Hrvatskoj, nego u čitavom svijetu, je vodeći problem turizma izražena sezonalnost koja utječe na neravnomjeran stupanj iskoristivosti kapaciteta, što se smatra jednim od najvećih problema svih turističkih destinacija. Svi čimbenici koji su uključeni u razvoj turističke destinacije i povećanje njezine kvalitete nastoje raznim oblicima selektivnog turizma produžiti turističku sezonu te povećati atraktivnost destinacije, a golf turizam je jedan od mogućih puteva (3). Strategijom se pored zdravstvenog turizma, cikloturizma, gastronomije i enologije, planinskog i ruralnog turizma i ekoturizma kao strateško opredjeljenje ističe snažan i sveobuhvatan razvoj golf turizama na preko 20, od prvobitno predviđenih 60 , najatraktivnijih lokacija duž Jadranske obale i neposrednog zaleđa, te u unutrašnjosti Istre sa širenjem prema atraktivnim hercegovačkim lokacijama. Vlada smatra da golf turizam predstavlja mogućnost još uspješnije gradnje imidža Hrvatske kao elitne destinacije, jer se nemogućnost igranja golfa u međunarodnoj javnosti sve češće naglašava kao ozbiljan minus hrvatske turističke ponude.

U ciljevima razvoja polazi se od pretpostavke da golf ponuda znatno više pridonosi atraktivnosti i boljoj popunjenosti postojećih smještajnih kapaciteta te većoj konkurentnosti turističkog sektora za investicije, u odnosu na drugu sportsko-rekreacijsku ponudu i sadržaje. Kvaliteta budućih igrališta trebala bi se ogledati u vrhunski projektiranim i okolišno odgovornim igralištima uklopljenim u razvijenu ponudu smještaja, uključujući i vrhunske hotele za goste najviše platežne moći (3).

Golf ponuda se planira razvijati u grozdovima (oko 5 igrališta na međusobnoj udaljenosti do sat vožnje automobilom), a golf grozdovi se planiraju na područjima koja su lako dostupna, klimatski povoljna, dobro infrastrukturno opremljena te $\mathrm{u}$ blizini većih turističkih i/ili urbanih aglomeracija. Hrvatska, prema Radić i sur., prepoznaje tri modela razvoja golf ponude, iako nije jasno za koji model se opredjeljuje pri najavi izgradnje 30 golf igrališta: golf igrališta bez komercijalnih smještajnih objekata, hotelski resort projekti s golfom i golf igrališta $\mathrm{s}$ pratećim smještajnim objektima (4) pri čemu se iz dostupne projekte dokumentacije vidi da se favoriziraju resorti i obilje pratećeg ugostiteljsko smještajnih kapaciteta $(5,6,7)$.

U aspektu potrebe zaštite okoliša od utjecaja izgradnje golf terena i popratnih sadržaja nema puno dostupnih podataka iako se deklarativno naglašava da se posebna pažnja planira posvećivati ekološkoj održivosti (npr. preferiranje devastiranih područja, ograničavanje gradnje $u$ zaštićenim i prostorima $s$ ograničenom dostupnosti vode, ograničavanje invazivnih zahvata u prostor i pejzaž itd.), a s ciljem da okolišno osjetljiva i igrališta projektirana u skladu 
s prirodnim okruženjem budu prepoznatljiv i diferencirajući atribut nove golf ponude $\mathrm{u}$ Hrvatskoj.

Trend izgradnje golf terena sa pratećim hotelskim i ugostiteljskim objektima ne zaobilazi ni susjedne zemlje. Ekspanzija razvoja golf turizma u regiji vidljiva je i kroz činjenicu da se na listi kapitalnih investicijskih projekata za Federacije Bosne i Hercegovine u sektorima poljoprivrede, energetike, industrije, prometa, turizma i zaštite životne sredine ukupne vrijednosti veće od 21,2 milijarde KM, koju je utvrdila Vlada Federacije $\mathrm{BiH}$, nalaze se i golf-tereni u Mostaru, čija će izgradnja, bez objekata, navodno stajati 50,000,000 KM (8).

Za razumijevanje izvedivosti i potencijalnih rizika tako postavljenih ciljeva, potrebno je analizirati utjecaj golf turizma na okoliš temeljem dostupne znanstvene literature, te provesti analizu na pojedinim slučajevima u kojoj se mjeri poštuje opredjeljenje projektiranja izgradnje okolišno osjetljivih i igrališta projektiranih u skladu s prirodnim okruženjem.

\section{CILJ}

U radu se analiziraju strateški ciljevi razvoja turizma u RH u kratkoročnom razdoblju vezani uz razvoj golf turizma u Hrvatskoj sukladno važećoj Strategiji, zatim analiziraju moguće utjecaja izgradnje golf turističkih kapaciteta na okoliš i lokalno stanovništvo, te procijenjuje usklađenost razvoja golf turizma sa održivim razvojem.

\section{METODE}

U radu su korišteni sekundarni izvori informacija koji su podvrgnuti postupcima indukcije i dedukcije, analize i sinteze, te metode komparacije, deskripcije i klasifikacije.

\section{REZULTATI I RASPRAVA}

Pođemo li od opće koncepcijske definicije turizma Svjetske turističke organizacije (UNWTO) prema kojoj „turizam uključuje sve aktivnosti proizašle iz putovanja i boravaka osoba izvan njihove uobičajene sredine ne dulje od jedne godine radi odmora, poslovnog putovanja i drugih razloga nevezanih uz aktivnosti za koje bi primili ikakvu naknadu u mjestu koje posjećuju, "golf turizam spada u posebnu skupinu turističkih kretanja koja su uvjetovana određenim, dominantnim turističkim motivom koji turističkog potrošača pokreće na putovanje $u$ destinaciju čija je turistička ponuda sadržajima prilagođena ostvarenju doživljaja vezanih uz dominantan interes pojedinoga potrošača, te je sukladno navedenom golf turizam namijenjen točno određenom, uskom segmentu turista (9).

Provedeno je niz istraživanja kojima je cilj bilo stvaranje profila turista koji dolaze na destinaciju isključivo kao igrači golfa. Peter (2010) ističe da igrači golfa dolaze iz svih dobnih skupina, oba spola, svih razina primanja, ali i iz svih obrazovnih skupina te različitih zanimanja. Sukladno rezultatima istraživanja muškarci igraju golf 2,5 puta više od žena, najčešće su pripadnici dobne skupine od 20-29 godina, te najviše igraju oni s najvećim osobnim primanjima. Po stupnju obrazovanja igrači s diplomom fakulteta predstavljaju $40 \%$ svih igrača, a među njima po profesijama najzastupljeniji su profesori, direktori i administracija koji čine čak $45 \%$ svih igrača (3).

Radić Lakoš i sur. navode da je prosječan golfer star između 35 do 55 godina, koji se zadrži do desetak dana na južnom Mediteranu baveći se golfom, prođe 3 do 4 terena, te potroši oko 150 eura dnevno (4).

Jelenković prenosi rezultate studije koju je proveo KPMG prema kojoj je također udio muškaraca u profesionalnom i rekreativnom igranju golfa dominantan, pri čemu su 63\% golfera u EU muškarci, 22\% žene, a $14 \%$ djeca. U 2013. godini udio muškaraca je porastao za $0,4 \%$, udio žena za $0,6 \%$ a udio djece je značajno pao u odnosu na raniju godinu (10).

Prema drugoj prenesenoj studiji Hennessey i suradnika pokazano je da se tradicionalno shvaćanje da su golferi većinom muškarci viših srednjih godina ili blizu umirovljenja značajno mijenja budući da se među turistima koji putuju radi golfa profiliraju tri grupe turista s obzirom na učestalost i frekvenciju putovanja. U navedenom istraživanju oni koji često putuju svrstani su u kategoriju „predanih golfera" i značajno se razlikuju od ostalih dviju skupina. Predani golferi su stariji, bogatiji, manje osjetljivi na promjenu cijene usluge i proizvoda, najčešće ne žive 
u obalnom području, te smještaj rezerviraju unaprijed, prije dolaska na destinaciju. Oni troše značajno više sredstava na odmoru i pripadaju kategoriji koja može ostvariti veliki ekonomski utjecaj u turističkoj destinaciji zbog visokih navika trošenja, učestalosti putovanja i visokih prihoda ili kumuliranog bogatstva (10).

Prema istraživanjima drugih autora poput Hudsona golf turisti tijekom boravka $u$ destinaciji na proizvod vezan uz korištenja golf terena troše $26 \%$ sredstava, na troškove putovanja $21 \%$, na smještaj $20 \%$, na gastronomiju $18 \%$, dok na ostalo troše $15 \%$ sredstava (11).

Uvažavajući navedeno, golf turizam predstavlja potencijalno visoko prihodovnu djelatnost ukoliko se usmjeri na kategoriju predanih golfera koji zbog blage klime u Hrvatskoj golf mogu igrati tijekom gotovo cijele godine i time značajno produljiti sezonu. Petar navodi da bi turizam Hrvatske izgradnjom golf igrališta dobio na atraktivnosti i ekskluzivnosti ponude, da bi poslovnim partnerima hrvatskih poduzetnika bili ponuđeni bogatiji sadržaji i ponuda tijekom boravka u Hrvatskoj, te da razvoj golfa podrazumijeva nove poslove i za domaća poduzeća, od projektiranja i izgradnje igrališta do marketinga turnira i smještaja gostiju. Donosi se tvrdnja da golf može pomoći Hrvatskoj u prestrukturiranju turističkih, proizvodnih, uslužnih, prometnih i infrastrukturnih kapaciteta (3).

Petar nadalje ističe i da „izgradnja golf igrališta znači također i investicije u infrastrukturu, prometnice, smještajne objekte, uslužne djelatnosti i industriju, te zaštitu okoliša, a zaključuje da „pritom ne bi bio narušen prirodni sklad čovjekove okoline"(3). Jelenković suprotno tome iznosi zaključak da „se tek manji broj golf terena izgradi uzimajući u obzir interes zaštite prirodnih površina" (10).

Kao najčešće prijetnje održivom razvoju i okolišu izdvajaju se problemi vezani uz korištenje prostora i intervencije u okolišu koje dovodi do gubitaka prirodnih površina i zahtijevaju dodatne velike potrebne količine vode za natapanje biljnih površina. Održavanje zelenila travnate površine povezano je je uz nužnost korištenja pesticida i gnojiva, a također je dokazan utjecaj na bioraznolikost koji može voditi u smjeru nestajanja bioraznolikosti. Nedvojbeno, cjelokupne aktivnosti razvoja golf turizma mogu voditi šteti u vrijednim prirodnim bogatstvima. Nezanemariv je i mogući utjecaj na lokalno društvo i stanovništvo, kao i pritisak prometa vezanog uz dolazak na destinaciju i ostalo.

Prve povijesne opozicije golfu javljaju se u Meksi$\mathrm{ku}$, a pogotovo u Aziji, posebno u zemljama gdje je golf prouzročio znatne štete u smanjenju vodnih resursa za piće, izvlaštenje zemljišta i sječu šuma. Golf kao nova prostorna aktivnost koja zahvaća velike površine, koristi puno vode te primjenjuje agrotehničke mjere s prihranjivanjem i zaštitom bilja. Uvrštena je u onu kategoriju objekata za koju je potrebno izraditi ocjenu utjecaja na okoliš (10).

Budući da se golf igra u prirodi neminovan je njegov utjecaj na stanje okoliša, kako od oblikovanja i izgradnje tako do održavanja i vođenja. Upravo su osobite značajke golfa oblikovanje igrališta strukturama krajobraza. Igrališta za golf mogu se graditi na kopnu, otocima, na obali i u unutrašnjosti poput projekta izgradnje golf terena u Mostaru, a koji svi predstavljaju krajobraznu agresiju kojom se trajno, više ili manje, narušava postojeća vegetacija i oblik krajobraza. Gledano s bioetičkog stajališta na taj način se nepotrebno i negativno utječe na ukupnu biološku i krajobraznu raznolikost čime se umanjuje vrijednost prostora. Naime, dolazi do gubitka staništa i vrsta, fragmentacije staništa i degradacije krajobraza, a moguće je i oštećenje kulturno - povijesne baštine. Izgradnja golf terena direktno mijenja najmanje više od stotinjak hektara prostora njegovim privođenjem drugoj namjeni, a ukupno cijeli kompleksi sa pratećim sadržajem i potrebnom infrastrukturom unose promjene na više stotine hektara prostora. Prema Petar za standardno golf igralište $\mathrm{s} 18$ rupa (staza) potrebna je površina od 40 do 60 hektara: pri razmjerno ravnom prostoru s malo šume potrebno je 40 hektara, dok je u prostoru koji je vrlo brdovit, s mnogo drveća i drugih prirodnih zapreka, potrebno i do 60 hektara. Za igralište s 9 rupa (staza) potrebno je 20-30 hektara (3).

Jelenković navodi da je za samo prosječno golf igralište s 18 polja potrebno iznimno mnogo prostora, u prosjeku oko 100 ha na kojem su smještene 
prirodne ili građene strukture. $\mathrm{Na}$ samo igralište otpada oko 20 ha, vježbalište čini dodatnih 2 ha, a ujezerene površine (često umjetne akumulacije) zauzimaju još 1-5 ha. Manji dio prostora zauzimaju klupska kuća $(0,5-0,8$ ha) i servisna zgrada $(0,5$ ha), oko kojih se uređuje okoliš (dodatnih 10 ha), pa na prirodni okoliš otpada preostalih 50 - 60 ha (7). Neovisno o veličini iskorištenog prostora, prilikom faze izgradnje odnosno ravnanja golf terena doprema se i koristi teška mehanizacija nakon čega krajolik bude ireverzibilno izmijenjen. Čak i ispod zemlje, arheološki se nalazi mogu oštetiti prolaskom teških strojeva, zemljanim radovima ili sadnjom biljaka (10).

S ekološkog i javnozdravstvenog aspekta za izgradnju golf terena kao lokacije se ne mogu koristiti zaštićena područja i nacionalni parkovi, te određena staništa koja treba zaštititi, zaštićene šume osobitog značaja, šume-izletišta i rezervati, prirodne šume kao i šume u gusto naseljenim područjima, područja s osobitim kulturno povijesnim, geološkim i geomorfološkim značenjem, te je upitno pravo korištenja i ostalih zaštićenih prostora bilo kao parkovima prirode ili u sklopu projekta Natura 2000 (5). Važno je izbjegavati nepotrebne zahvate u postojeće visokovrijedne strukture staništa, npr. u vlažna područja, prirodne vode, $u$ suhe i siromašne površine kao i krčenje šuma i polja i nasipa obraslih grmljem, pojedinih stabala ili skupina stabala. Oblikovanje golf igrališta treba prilagoditi tipičnim odlikama regionalnog ili za lokaciju specifičnog kultiviranog krajolika te ga najbolje održavanjem struktura staništa i postojećeg reljefa staništa uključiti u izgled krajolika. Prilikom održavanja izgrađenog golf igrališta pored utjecaja na krajobraz, multipliciraju se i drugi negativni utjecaji na okoliš.

Prvenstveno treba istaknuti izrazito negativan utjecaj na vodoopskrbu. Voda na igralištu koristi se za sanitarno - potrošne namjene, a drugi, značajniji dio za zalijevanje. Godišnja potrošnja vode za zalijevanje travnjaka ovisi o klimatskim uvjetima (temperaturi, vlazi, vjetru, padalinama, izloženosti), morfologiji i strukturi tla, vrsti travnjaka, načinu upravljanja travnatim površinama, pritisku prometa i rasponu zalijevanih površina, ali višestruko premašuje uobičajenu potrošnju vode u lokalnoj zajednici.

Posebno intenzivno zalijevanje vrši se na početnim i završnim područjima igrališta, uključivši i rubna područja, površinama staza te rubnim područjima staza. Kako bi se smanjila potrošnja vode za zalijevanje sve veća pažnja usmjerava se na selekciju trava, predstavnika autohtone flore ili na izbor suši otpornijih varijeteta, a također se povećava pažnja o kvaliteti tla tj. supstrata.

Međutim, usprkos svim naporima za minimalizacijom količina utrošene vode, dnevno se troši za zalijevanje golf terena oko $1500 \mathrm{~m}^{3}$ vode (kao grad s 8000 stanovnika) tj. $6000-8000 \mathrm{~m}^{3}$ po hektaru godišnje što je prema nekim autorima 3 - 4 puta više od prosječnih potreba za vodom u poljoprivredi.

Osim potrošnje vode, kao dodatan problem sa bioetičkog stajališta javljaju se i etički konflikti budući da se na iskorištenom zemljištu ne proizvodi hrana, već se tlo i voda troše u sportske svrhe, a u obalnim zonama dodatni problem je mogućnost zaslanjivanja podzemnih voda zbog prekomjernog crpljenja.

Godišnje se za tretman dijelova igrališta po hektaru utroši oko $400 \mathrm{~kg} \mathrm{~N}$, oko $200 \mathrm{~kg} \mathrm{P}_{2} \mathrm{O}_{5}$, te oko $300 \mathrm{~kg} \mathrm{~K} \mathrm{O}_{2} \mathrm{O}$. Uz gnojiva se apliciraju i velike količine sredstava za zaštitu bilja koja također mogu onečistiti obližnje vode (podzemne i/ili nadzemne).

Sukladno objavljenim podacima u Kaliforniji npr. jedno golf igralište od 18 rupa troši i $3000 \mathrm{~m}^{3}$ vode dnevno (dovoljno za osobnu upotrebu oko 15.000 stanovnika) te čak do 2 tone kemijskih gnojiva, herbicida i pesticida godišnje.

U golf destinacijama na Malajskom poluotoku, Polineziji i Filipinima zbog klimatskih uvjeta jedno golf igralište od 18 rupa dnevno troši po 5000 prostornih metara vode, što je dovoljno za oko 60.000 tamošnjih seoskih stanovnika, a upotreba kemikalija po igralištu iznosi i do 4 tone godišnje. Navodi se podatak da je zbog pomanjkanja vode za navodnjavanje i zagađenih okolnih zemljišta krajem osamdesetih godina došlo do masovne gladi i migracije seljaštva u gradska područja.

Kao alternativna rješenja koja mogu smanjiti, iako ne i otkloniti potrebu za trošenjem vode $u$ 
svrhu navodnjavanja, ističe se korištenje senzora za detekciju vlažnosti tla koji se ugrađuju ispod površine terena koji se navodnjava sukladno potrebama a ne vremenskim ritmom rada sustava za navodnjavanje. Dio vode za navodnjavanje moguće je dobiti reciklažom otpadnih voda iz smještajnih kapaciteta koje nije moguće vratiti u ljudski uporabu.

Moguće je korištenje alternativnih vrsta trava koje su prilagođene atmosferskim i drugim uvjetima u kojima je izgrađen golf teren. Dobar odabir vrste trave nužan je kako bi se smanjila potrošnju vode. Cynodon spp, Zoysia spp, Paspalum vaginatum $i$ Buchloe dactyloides su vrste trava s najmanjim potrebama vode. Uporaba bočate ili pak morske vode, može se uvesti kao dodatak drugim izvorima vode. Međutim na taj način ne rješava se problem zaslanjivanja podzemnih voda. Zbog toga se desalinizacija čini kao skuplje, ali prihvatljivije rješenje od navodnjavanja slanom vodom.

Prikladno dizajnirani sustavi za zalijevanje, posebice $u$ pogledu raspona (najmanje dvostruki ili trostruki), pokrivenosti (100\% ili možda više), broju raspršivača i kapilarnoj distribuciji vode preporučljivi su u svakoj situaciji oskudice vode. Dio ušteda moguće je dobiti i promjenom ekološke svijesti igrača kojima intenzivno zelenilo trave u nevegetacijskim periodima godine nije presudno za igranje golfa, već je stvar navike i očekivanja.

Uz to što se opterećuje postojeća vodoopskrbna mreža i direktno povećava zahvat (pitke) vode iz rezervoara, golfom se povećava mogućnost kontaminacije podzemnih ležišta pitke vode aplikacijom gnojiva. Količina korištenog gnojiva ovisi o vrstama trave, vrsti tla, vrsti korištenog gnojiva, brzini rasta trave, metodi primjene (npr. tekuće ili kruto), hranjivim sastojcima koji su već prisutni u tlu i - odstranjivanju pokošene trave.

Istraživanja o ponašanju apliciranog gnojiva nisu brojna. Prema istraživanju US Geological Survey na gotovo svim uzorcima vode prikupljenim u rijekama i jezerima u blizini golf terena pronađene su količine pesticida više od dozvoljene (12).

Jedno od njih provedeno u Padskoj dolini (Italija) ukazuje da se u dolini rijeke Pad (Po), nalazi 60 golf igrališta s najmanje 18 rupa. Počevši od 2005. godine, radna skupina koju čine stručnjaci IGF-a (Talijanske Golf Federacije) i GEE (Golf Environment Europe - Europska golf asocijacija za okoliš), ispitivala je stvarnu potrošnju gnojiva, pesticida i vode na travnjacima pojedinih golf igrališta. U suradnji s lokalnim upraviteljima sastavljen je bio ogledni uzorak od 16 golf igrališta (26,6\% od ukupnog broja), od čega 12 igrališta s 18,2 s 27 , te 2 s 36 rupa, prosječne površine 77 hektara. Prema prikupljenim podacima, prosječna godišnja potrošnja vode po golf igralištu iznosi $1.339,9 \mathrm{~m}^{3} / \mathrm{ha}-1$, a što se gnojiva i kemijskih sredstava tiče, podaci govore o potrošnji od $39,8 \mathrm{~kg} /$ ha-1 dušika $(\mathrm{N}), 6 \mathrm{~kg} / \mathrm{ha}-1$ fosfora $\left(\mathrm{P}_{2} \mathrm{O}_{5}\right), 33,3 \mathrm{~kg} /$ ha-1 kalija $\left(\mathrm{K}_{2} \mathrm{O}\right), 1,7 \mathrm{~kg} / \mathrm{ha}-1$ herbicida, $3,5 \mathrm{~kg} / \mathrm{ha}-1$ fungicida te $1,9 \mathrm{~kg} / \mathrm{ha}-1$ insekticida.

Do devedesetih godina kroz pesticide u tlo i vode su se unosile velike količine kadmija i arsena kao teških metala, međutim uporaba pesticida pa time i teških metala posljednjih godina se smanjuje zbog prelaska na korištenje bioloških i sporotopljivih pesticida.

Dio pesticida koristi se i za suzbijanje štetnika, uključujući i komarce. Alternativno je moguće smanjiti količinu pesticida uvođenjem zajednice šišmiša u prostor kao prirodnih neprijatelja komaraca.

Iako je upitna smislenost usporedbe opterećenja po okoliš kojeg proizvodi poljoprivredna proizvodnja kojom se proizvodi hrana i opterećenja kojeg proizvodi golf turizam, neki autori koji zagovaraju razvoj golf industrije poput Curića ističu kako se na travnatim površinama golf igrališta, $u$ okviru istih površina, upotrebljavaju manje količine gnojiva i fitosanitetskih proizvoda u odnosu na uobičajene intenzivne poljoprivredne kulture (13).

Zagovornici golf turizma vrlo često kao snažan argument ističu činjenicu da golf tereni manje opterećuju okoliš od korištenja zemljišta u poljoprivredne svrhe. Nadalje Curić donosi usporedbu potrošnje vode, gnojiva i insekticida u poljoprivredi i golfu pri čemu je prema njemu potrošnja veća u poljoprivrednoj proizvodnji. Bioetičari međutim problem sagledavaju puno šire budući da poljoprivreda proizvodi hranu u uvjetima svjetske gladi, a golf resorti troše resurse za dokolicu ili ostvarivanja profita bogatih zemalja (13). 
Golf igrališta također obuhvaćaju brojna staništa cijelog niza raznih biljnih i životinjskih vrsta, od kojih mnoge polako nestaju iz prirodnog okruženja kao posljedica narušavanja ili nestanka potrebnih prirodnih područja, lova te fitosanitetskih proizvoda koji se sve više koriste u poljoprivredi. Posebno je indikativan pokušaj izgradnje golf terena u neposrednoj blizini PP Vransko jezero i Ornitološkog rezervata. Iako se u Studiji utjecaja na okolinu izbjegla procjena utjecaja izgradnje terena na populaciju ptica koje žive uz Vransko jezero (5), i iako je naknadnim uvrštavanjem mišljenja angažiranog ornitologa (6) ponuđena tvrdnja da investicija ne bi trebala utjecati na okoliš i faunu, Uprava za zaštitu prirode Ministarstva kulture - Mišljenjem (klasa 612-07/0901/1710, 8.2.2010.) potpuno suprotno tvrdnjama investitora i sukladno zdravoj pameti očitovala se da izgradnja golf terena u neposrednoj blizini PP Vransko jezero na način da nije moguće isključiti negativne utjecaje predmetnog zahvata na ciljeve očuvanja i cjelovitosti područja ekološke mreže.

U Mišljenju se izrijekom tvrdi da se „planirani zahvat nalazi unutar područja ekološke mreže HR100000024 Ravni kotari kao međunarodno važnog područja za ptice, te neposredno u blizini još jednog važnog područja za ptice HR 100000025 Vransko jezero i Jasen, te važnog za divlje svojte i stanišne tipove HR20000914 Ornitološki rezervat Vransko jezero i Jasen. Utjecaji planiranog zahvata na područje ekološke mreže Ravni kotari očituje se u gubitku staništa, manjim dijelom (10\%) izgradnjom smještajnih kapaciteta, a većim dijelom uslijed zamjene autohtone vegetacije neautohtonom travnatom površinom. Primjena velike količine pesticida i gnojiva potrebnih za održavanje golf terena može, uslijed ispiranja voda s golf terena, ugroziti područje ekološke mreže HR 10000025 i HR 2000914 i dovesti do promjena kvalitete vode u Vranskom jezeru. Navedeno može imati negativan utjecaj na staništa biljaka i ostale organizme. Tijekom izgradnje golf terena moglo bi doći do ispiranja zemlje i Vransko jezero te do uznemiravanja ptica na području samog zahvata, te s obzirom na malu udaljenost zahvata od jezera, onih ptica koje dolaze na područje Vranskog jezera. Uz istočnu granicu golf igrališta nalazi se prostor također namijenjen igralištu za golf koji zajedno sa tri druga golf terena predviđena Prostornim planom Zadarske županije predstavlja kumulativni utjecaj na navedena područja ekološke mreže napose izgradnjom smještajnih kapaciteta što za sobom povlači dodatnu značajnu potrošnju vode i neminovno uznemiravanje ptica, a Elaborat koji je podnesen ne obrađuje niti na koji način kumulativni efekt s drugim planiranim zahtjevima u okolnom području."

U većini slučajeva, kao i u navedenom primjer, prema Jelenković prilikom realizacije golf projekata bioraznolikost životinjskih i biljnih vrsta postane žrtvom profita investitora (10).

Smanjenje bioraznolikosti raste zbog aktivnog igranja na području cijelog golf terena, a posebice nakon uporabe pesticida zbog održavanje terena $\mathrm{u}$ idealnom i estetski igračima očekivanom stanju potpunog zelenila usprkos klimatskim promjenama i varijacijama godišnjih doba. Prisutnost golf turizma u prirodnom staništu posebice prisutnost čovjeka i popratne opreme uključujući i rasvjetu neminovno dovodi to promjena u ponašanju životinja, njihovoj reprodukciji, psihologiji i općem zdravlju te vodi u smrt većeg broja jedinki, neovisno o ponašanju samih golfera (10). Upravo na tom prikazu slučaja posve je neprihvatljivo da se odobrava izgradnja golf resorta na području koje je unutar područja ekološke mreže, a posebice Parka prirode Vransko jezero u kojem je dosada zabilježeno oko 235 vrsta ptica, od čega 102 gnjezdarice (ponajviše ptica močvarica), dok je ostalima jezero odmorište prilikom selidbe ili zimovalište. Prema procjenama u parku za jesenje selidbe dnevno boravi između 20.000 i 200.000 ptica.

Drugi autori, poput Curića problemu utjecaja na bioraznolikost pristupaju na drugačiji način. Curić golf terene vidi i kao rezervate koji u urbanim ili ugroženim područjima mogu doprinijeti očuvanju bioraznolikosti te navodi da golf igrališta mogu predstavljati područja zaštićena od čovjekovog utjecaja. Boljim poznavanjem životinjskih vrsta koje žive u krugu golf igrališta te inicijativa za njihovu zaštitu, oni koji su nadležni za upravljanje igralištem mogu dati značajan doprinos očuvanju 
bioraznolikosti (13). Kao alternativa izgradnji golf terena u takvim ornitološkim rezervatima moguć je razvoj ekoturizma sa specifičnim sadržajima poput „bird watchinga“ tj. programa promatranja ptica.

Većinom se u nekoj destinaciji koja se odluči usmjeriti na golf-turizam stvaraju tzv. golfski-klasteri, područja s pet ili više igrališta koja sa smještajnim kapacitetima u okolici čine prepoznatljiva turistička odredišta poput portugalske regije Algrave, turske regije Antalya, te španjolskih Costa del Sol i Mallorca koji multiplikativno opterećuju okoliš.

Uz golf se često vežu turizam i prodaja nekretnina te je stoga investiranje u golfersko - turističku sferu unosnija od klasične investicije u nekretnine. Gradnja nekretnina, a posebice apartmana, u sklopu golf kompleksa opravdava se početnom nerentabilnošću golfa i amortizacije održavanja igrališta. Investiranje u klasično golf igralište bez nekretnina podrazumijeva dugo vraćanje uloženog kapitala (i do 40 godina) što predstavlja velik rizik za investitore.

Uz apartmanizaciju, golf je u nekim sredinama postao izgovor za urbanizaciju, a česte su zamjerke da se područje planirano za golf zatvara, tj. izdvojeno razvija bez povezanosti s lokalnom zajednicom.

Izgradnja smještajnih kompleksa je neizbježna budući da su početna ulaganja u golf iznimno visoka. Neki autori iznose podatke da se u prosjeku za jedno golf-igralište s 18 polja ulaže oko $6,000,000$ eura. Zbog velikih ulaganja procjenjuje se da je nivo rentabilnosti minimalno 15.000 partija golfa godišnje, pri čemu je neminovno da se samoodrživost ostvaruje iznajmljivanjem, a profit etažiranjem, a i kasnijom prodajom smještajnih kapaciteta.

Samo golf igralište bez drugih sadržaja niskoprofitna je investicija. Ono je sredstvo prijenosa, koji otvara vrata drugim investicijama (u graditeljstvu, turizmu, prometu, itd.), jer golf igralište bez okruženja zanimljivog prije i nakon igranja, mjesto je okupljanja samo najzagriženijih golfera. Od ukupnog godišnjeg prihoda od golfa, udio golf igrališta iznosi samo $10 \%$. Preostalih $90 \%$ donose hoteli, restorani, trgovine, prijevoznici, graditelji, druge uslužne djelatnosti te svi ostali popratni sadržaji i akcesorne usluge (3).
U prilog kritičarima razvoja golf turizma kao mogućeg paravana za apartmanizaciju prostora ide u prilog i stav prema kojem isplativost golf igrališta može biti zasnovana na blizini velikim središtima i na velikom broju članova u pripadajućem golf klubu. U drugim područjima, gdje ne postoji svakodnevno velik broj igrača koje privlači blizina igrališta, investitori privlače ljude ili ponudom kuća i stanova u blizini golf igrališta ili na osnovi njihova boravka u hotelu tijekom njihova odmora (3).

Planom izgradnje golf terena u blizini Mostara na površini od 106 hektara, 15 kilometara sjeverno od Mostara i 22 kilometra od Međunarodne zračne luke Mostar, uz lijevu obalu rijeke Neretve, predviđena je izgradnja golf-terena s pratećim sadržajima: 151 vila, 6 poslovnih objekata i 5 javnih objekata prilog je tezi da izgradnja golf terena postaje zapravo izgovor za građevinski sektor, budući da proizlazi da golf predstavlja jednu od najprofitabilnijih građevinskih djelatnosti u turizmu u razvijenim zemljama. $\mathrm{S}$ obzirom na ekološku štetu i mogući zdravstveno ekološki rizik kao posljedica iscrpljivanja ležišta i zaliha pitke vode te zagađenja podzemlja i okoliša pesticidima herbicidima i insekticidima, ostaje upitna dugoročna profitabilnost golfa koja navodno proizlazi ne samo od direktnih prihoda od korištenja terena, već je golf turistima moguće plasirati i lokalne proizvode (vrhunska vina, originalna ruralna jela), organizirati posebne izlete te ostale oblike rekreacije i zabave. Multiplikativni efekti dodatno se mogu osnažiti umrežavanjem usluga, proizvoda i ponude naselja, sela i gradova u blizini pojedinih golf terena (13). Naravno sve pod uvjetom da netaknuta priroda doline Neretve i Jadransko obale ostane jednako tako netaknutom i ekološki očuvanom i nakon realizacije projekta na području Željuše, a lokalno stanovništvo zaštićeno od rizika s obzirom da je lokacija golf terena na sjevernom ulazu u Mostar u neposrednoj blizini Neretve (16). 


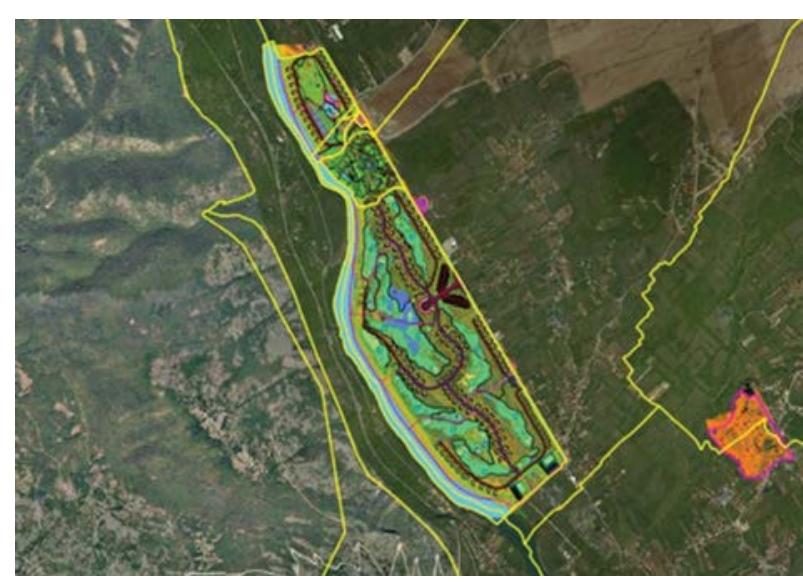

Slika 1. Lokacija golf terena na ulazu u Mostar u neposrednoj blizini Neretve

Izvor fotografije: http://bljesak.info/rubrika/business/clanak/mostar-golf-tereni-u-mostaru-jos-uvijek-na-cekanju/176621

\section{ZAKLJUČAK}

Zaključno, stavovi članova udruga za zaštitu prirode i lokalnih inicijativa i jednog dijela struke vide u golf turizmu prijetnju za održiv razvoj, dok drugi dio struke i investitori te dio lokalne političke vlasti u golf turizmu vidi mogućnost razvoja turizma i lokalne zajednice.

Izrečene, međutim nedovoljno znanstveno argumentirane stavove, citiranjem prenose $\mathrm{u}$ svojim radovima i drugi autori pri čemu je ipak potrebno obazrivo i znanstveno neutralno i objektivno razmotriti argumente obaju suprotstavljenih strana kako bi u konačnici, politička odluka kroz struku, prilikom implementacije ostavila što manji negativan učinak na okoliš (15).

Upravo zbog različitih i oprečnih viđenja istog problema, analiza zdravstveno ekoloških posljedica utjecaja izgradnje golf terena čini se nužnom. Javni interes dodatno opravdava potrebu promjene načina izrade studija utjecanja na okoliš kako one ne bi postale paravan za pogodovanje investitorima koji izradu studija i naručuju vođeni realizacijom vlastitog partikularnog financijskog interesa investitora. Hrvatska i Federacije Bosne i Hercegovine su još uvijek nedovoljno turistički izgrađene i imaju relativno nezagađeni okoliš, pri čemu neizgrađenost podrazumijeva nedostatak infrastrukture koja je neophodna za elitni turizam. Ta činjenica istodobno predstavlja i prednost, jer još uvijek ima dovoljno prostora koji nije popunjen hotelskim objektima niže kvalitete namijenjenih masovnom turizmu, a uz dobru razvojnu strategiju bi se mogao pretvoriti u elitnu destinaciju, pri čemu postoje i alternativna rješenja u odnosu na ekološki upitan golf turizam - ekoturizam, vinski turizam, industrijska baština iskorištena u turističke svrhe, kulturni turizam, wellness i zdravstveni turizam i sl. Kod utvrđivanja vizije i strategije razvoja i podizanja kvalitete destinacije svi dionici moraju biti aktivno uključeni u definiranje modela budućega razvoja kojim se treba očuvati ono što imamo, ali mora se uvijek imati u vidu i činjenicu da potencijalni investitor koji je spreman uložiti svoja financijska sredstva želi ostvariti i višak vrijednosti, odnosno imati rentabilno poslovanje, pri čemu je profit i održivost investicije investitoru iznad održivog razvoja. Izgradnja svih vrsta kapaciteta i stopa porasta broja ležaja u destinaciji treba maksimalno štititi prostor i prirodu kao dugoročni temeljni preduvjet interesa razvoja turizma.

Budući ciljevi razvoja trebaju biti mjerljivi, jasni, transparentni i ostvarivi, usmjereni na razvoj temeljen na načelima održivosti, odnosno održivi razvoj kao koncepciju, koja osigurava dugoročni boljitak lokalnom stanovništvu i zajednici s jedne strane, te zadovoljstvu turista kao korisnika proizvoda i/ ili usluge s druge strane. Kvalitativna načela razvoja moraju se uvažavati jednakovrijedno kao i kvantitativna jer svako odstupanje od takvog razumijevanja međuovisnosti kvantitete i kvalitete najozbiljnije prijeti daljnjem dugoročnom razvoju turističke privrede kao i održivom razvoju u cjelini.

\section{LITERATURA}

1. Ministarstvo turizma RH. Strategija razvoja turizma do 2020. godine, dostupno na http:// www.mint.hr/UserDocsImages/Strategija-turizam-2020-editfinal.pdf

2. Vlada RH. Zaključak Vlade RH od 26. kolovoza 1999. o prihvaćanju Programa razvitka golfa kao elementa razvojne politike hrvatskog turizma. Zagreb: Vlada RH;1999.(dostupno na: https:// www.google.hr/url?sa=t\&rct=j\&q=\&esrc=s\&source $=$ web $\& c d=5 \&$ ved $=0$ ahUKEwi4yd7689PSA - 
h V B u B Q K H S i D x s Q F g g 1 M A Q \& u r l=https\%3A\%2F\%2Fwww.istra-istria.hr\%2Ffileadmin\%2Fdokumenti\%2Fgolf\%2F31Zakljucak_26081999.doc\&usg=AFQjCNHgOHVvSofLHlc49dqnT-mvIL3pwQ\&sig2=JKS1oJFwfA_ cSvLIU9-NUw, pristupljeno 1.3.2017.)

3. Petar S. Razvoj turizma izgradnjom golf igrališta, Acta Turistica Nova, 2010; 4:55-80.

4. Radić Lakoš T., Goleš D, Šišak A. Analiza utjecaja izgradnje golf igrališta na povećanje stupnja iskoristivosti turističkih kapaciteta Šibensko-kninske županije te povećanja kvalitete turističke destinacije. Zagreb: Hrvatsko društvo za kvalitetu; 2011.

5. Galaso I. Studija utjecaja na okoliš za golf igralište Baštijunski Brig, Biograd n/m. Zagreb: Fakultet strojarstva i brodogradnje Sveučilišta u Zagrebu; 2010.

6. Radović D. Mišljenje o utjecaju izgradnje golf igrališta Baštijunski Brig. Zagreb: Hrvatsko ornitološko društvo; 2010.

7. Sošić L. Valorizacija krajobraznog prostora - golf igralište na Srđu - Dubrovnik. Rovinj: Studio za krajobraznu arhitekturu, prostorno planiranje, okoliš, d.o.o.;2012.

8. Vidaček Lj. Engleska tvrtka će graditi golf-terene u Mostaru, imat će 151 vilu i 11 objekata. Večernji list (29.6.2016.) (dostupno na http://www. vecernji.ba/engleska-tvrtka-ce-graditi-golf-terene-u-mostaru-imat-ce-151-vilu-i-11-objekata-1095503, pristupljeno 1.3.2017.)
9. Svjetsko vijeće za putovanje i turizam (WTTC). Economic Impact. WTTC; 2010.

10.Jelenković E. Golf turizam. Pula: Sveučilište Jurja Dobrile u Puli, Fakultet ekonomije i turizma 'Dr. Mijo Mirković"; 2015.

11.Hudson S, Hudskon. L. Golf Tourism. Oxford: Goodfellow Publisher Limited; 2009.

12.US Geological Survey. Pesticides in the Nation's Streams and Ground Water, 1992-2001. USGS;2001. (dostupno na https://www.wateronline.com/doc/report-pesticides-in-the-nations-streams-and-0001, pristupljeno 1.3.2017.)

13.Curić, B. Analiza okvirnih mogućnosti razvoja golfa na području Istarske Županije. Pula: Istra golf dizajn d.o.o.; 2007.

14.Jeremić, Z. Golf turizam: Izazovi i perspektive razvoja. Doktorska disertacija. Osijek: Sveučilište u Osijeku; 2013.

15.Prenković, S. Stanje i mogućnost razvoja golf turizma u Republici Hrvatskoj. Čakovec: Međimursko Veleučilište u Čakovcu; 2014.

16. Anonimus. Golf tereni u Mostaru još uvijek na čekanju. Bljesak.info.;2016. (dostupno na:http:// bljesak.info/rubrika/business/clanak/mostar-golf-tereni-u-mostaru-jos-uvijek-na-cekanju/176621, pristupljeno 1.3.2017.) 


\title{
HEALTH AND ENVIRONMENTAL ASPECTS OF THE DEVELOPMENT OF GOLF TOURISM IN CROATIA AND BOSNIA AND HERZEGOVINA
}

\author{
Aleksandar Racz \\ University of Applied Health Sciences, Zagreb, Republic of Croatia
}

\begin{abstract}
INTRODUCTION: In the sub-sectors of tourist offer, which are marked as "subdivisions with a marked perspective of development", in the Tourism Development Strategy of the Republic of Croatia (CRO) by 2020, golf tourism is also highlighted. The expansion of the development of golf tourism in the region is also visible through the fact that there are also golf courses in Mostar on the list of capital investment projects for the Federation of Bosnia and Herzegovina (FBiH). Since the site selection and compilation of mandatory Environmental Impact Assessments does not evaluate the negative impacts of interventions on landscape, habitat and environment, a precautionary principle is required for the construction of a golf course. The expansion of the development of golf tourism in the region is also visible through the fact that the list of capital investment projects for the Federation of Bosnia and Herzegovina (FBH) contains also golf courses in Mostar. Since the site selection and compilation of mandatory Environmental Impact Assessments does not evaluate the negative impacts of interventions on landscape, habitat and environment, a precautionary principle is required for the construction of a golf course.

OBJECTIVE: To analyze the negative consequences of the construction of the golf resort on the environment and to awaken potential health and environmental effects when approving the construction of a golf course near Mostar.

METHODS: Secondary sources of information that were subjected to induction and deduction, analysis and synthesis, comparative, descriptive and classification methods were used in this paper.

RESULTS: Every construction of a golf course contributes greatly to the devastation of the landscape, and the biodiversity of animal and plant species becomes a victim of the profit of the investor. From the health and ecological aspect, the most important is the high water consumption for irrigation of golf courses and supporting facilities, with the negative consequences of the reduction of underground water resources in the wellspring and the bioaccumulation of artificial fertilizers, pesticides, insecticides and herbicides.

CONCLUSION: The price paid by the environment and the risk to the local community is too great in relation to the benefits gained through the development of golf tourism. The experience of the Republic of Croatia must also be important for the area of Bosnia and Herzegovina since the damage caused to the environment and the dangers to the health of the local population do not justify clientelism and favor the financial gain of a narrow circle of investors in the construction of a golf course as an excuse for apartment occupation.
\end{abstract}

Key words: Biodiversity, pesticides, water, sustainable development, golf tourism

Correspondence:

Asst. Prof. Aleksandar Racz

E mail: aracz@zvu.hr 